\title{
O sistema de justiça criminal na perspectiva da antropologia e da sociologia
}

\author{
Rodrigo Ghiringhelli de Azevedo ${ }^{1}$ \\ Jacqueline Sinhoretto ${ }^{2}$
}

Realizamos aqui uma revisão bibliográfica de artigos publicados entre 2012 e 2017 sobre justiça criminal no Brasil, em revistas A1 e A2 das áreas de sociologia e antropologia (listadas pelo Qualis Capes)3, e de teses de doutorado defendidas no período nos programas de sociologia e antropologia.

Foram utilizadas as palavras-chave "justiça penal" e "justiça criminal", o que levou a uma quantidade enorme de resultados nas buscas eletrônicas. Selecionamos inicialmente a área (antropologia e sociologia)4, depois o assunto, considerando o recorte proposto pelos editores, segundo o qual estudos sobre polícia e policiamento e estudos sobre encarceramento e prisóes náo estariam no escopo da nossa leitura.

Também não tratamos das produções sobre justiça juvenil e medidas socioeducativas aplicadas a adolescentes em razão de sua especificidade, merecedora de uma análise detida. As produçóes foram numerosas num período em que se discutiu a redução da maioridade penal e o balanço de duas décadas de implementação do Estatuto da Criança e do Adolescente.

A seleção levou a um recorte não homogêneo. Diante disso, o exercício foi colocar em perspectiva o que foi publicado nos últimos cinco anos sobre a justiça criminal nas revistas mais conceituadas da área, analisando temas, enfoques, metodologias e resultados.

Chama atenção que muitas revistas conceituadas náo tenham publicado sequer um artigo sobre o tema, ou tenham publicado esparsamente. A produção sobre a temática está concentrada em um grupo pequeno de periódicos, o que deixa evidente que suas políticas editoriais são decisivas para a visibilidade dos estudos produzidos. Por isso a nossa iniciativa de consultar as teses de doutorado finalizadas

1 Doutor em sociologia pela Universidade Federal do Rio Grande do Sul (UFRGS), professor titular da Pontifícia Universidade Católica do Rio Grande do Sul (PUC-RS), Bolsista de Produtividade do CNPq, membro do InEAC. E-mail: rga_2006@hotmail.com

2 Doutora em sociologia pela Universidade de São Paulo (USP), professora do Departamento de Sociologia da Universidade Federal de São Carlos (UFSCar), Bolsista de Produtividade do CNPq, pesquisadora do InEAC. E-mail: jacsin@uol.com.br

3 Em relaçấo aos artigos, selecionamos os que se referiam a pesquisas sobre o Brasil em revistas estrangeiras e pesquisas desenvolvidas e publicadas no país, utilizando as plataformas de busca SciELO e Redalyc, com palavras-chave, e pesquisa direta nos sites das revistas, consultando os números um a um, para checagem. As teses foram pesquisadas no Banco de Teses da Capes, utilizando as palavras-chave.

4 Existem numerosas produçôes da área do direito e algumas da psicologia, as quais foram excluídas desta leitura, tendo sido mantidas as produçóes que estão na interface com as ciências sociais, sobretudo trabalhos com pesquisa empírica. Não foram consultadas as revistas da área de ciência política, embora as revistas de sociologia publiquem com frequência estudos de cientistas políticos, os quais foram incluídos aqui. 
no período, para procurar maior abrangência na seleção ${ }^{5}$ e aumentar a visibilidade das teses.

Também é evidente que o tema da justiça criminal foi menos abordado no período do que os temas relativos à segurança pública, polícias e prisóes. É possível que a menor presença relativa dos estudos sobre a justiça, em comparação com as questóes de políticas de segurança e penitenciárias, seja reflexo de um período efervescente de iniciativas, especialmente do Governo Federal, na tentativa de repensar a estruturação nacional do setor, bem como da retomada do debate acadêmico sobre o encarceramento, no contexto do grande crescimento da população carcerária e do surgimento de novos elementos na dinâmica prisional, em especial as chamadas facçóes criminais.

Por outro lado, a relativamente reduzida produção sobre o funcionamento da justiça criminal talvez reflita uma ideia corrente de que os processos de criminalização são menos importantes do que as dinâmicas sociais da criminalidade, e de que as polícias teriam o papel preponderante na relação entre Estado e sociedade. $\mathrm{O}$ contexto atual de judicialização da política e politização da justiça penal e a cada vez maior espetacularização do processo penal no Brasil contrariam essa percepção. Vemos uma lacuna importante a ser explorada, especialmente no que se refere a abordagens sociológicas e antropológicas do impacto de novos procedimentos judiciais e de mudanças ou permanências de mentalidades ou representaçóes sociais sobre crime e castigo e sobre o papel da justiça penal.

A área de estudos sobre crime, polícia e justiça no Brasil cresceu, e alguns temas ganharam relativa autonomia em suas discussóes, havendo um conjunto de pesquisas que procura relacionar essas dimensóes. Não é possível compreender o funcionamento da justiça penal sem analisar o trabalho da polícia judiciária por meio do inquérito policial, assim como náo se pode compreender o encarceramento sem se analisar como o Poder Judiciário incorpora inovaçóes que teriam a perspectiva de reduzir a utilização da prisão, como a nova Lei de Drogas (Lei no 11.343, de 23 de agosto de 2006) ou a Lei das cautelares no Processo Penal (Lei no 12.403, de 4 de maio de 2011), alterando o efeito esperado.

\section{Padrões de administração de conflitos criminais e modelos de justiça}

Um primeiro âmbito de questôes abordadas nos trabalhos publicados no período diz respeito ao debate sobre o modelo de justiça penal brasileiro, suas conexóes com a estrutura social ou com elementos culturais próprios das nossas instituiçóes de justiça.

Neste âmbito, os trabalhos de Roberto Kant de Lima (2013) e dos pesquisadores a ele vinculados (KANT DE LIMA; MOUZINHO, 2016), através do Instituto Nacional de Estudos Comparados em Administração de Conflitos (INCT-InEAC), têm se destacado na tentativa de compreender o funcionamento da justiça e suas permanências, mesmo quando se implementam mudanças ou reformas legais ou institucionais.

Em artigo publicado por Kant de Lima e Mouzinho (Ibid.), é analisada, de forma bastante original, a dinâmica das açóes penais relacionadas com o chamado "Mensalão" e com a Operação Lava Jato. Para os autores, essas açóes apenas tornaram mais evidentes e

5 A dificuldade em revisar a produção publicada em revistas do estrato B é que elas são numerosas e muitas não estáo nas plataformas unificadas de busca, como SciELO e Redalyc, o que tornaria o trabalho de revisão inviável para os autores diante do calendário de execução. Daí a opção por consultar o Banco de Teses da Capes, que aumentou a abrangência das produçóes e imprimiu atualidade. 
de domínio público os procedimentos rotineiros da justiça penal no Brasil no trato das infrações atribuídas a réus de classes populares, caracterizando o que os autores denominam produção e reprodução da tradição inquisitorial no Brasil.

Em outro artigo publicado nesse período, Kant de Lima (2013) discute os padróes éticos que orientam a atuação da polícia e da justiça no Brasil, sustentando que estes náo são conformados pela lei ou por protocolos oficiais de atuação, mas se tornam explícitos somente quando chamam a atenção da opiniáo pública em situaçóes "ruidosas" envolvendo agentes dessas instituiçóes. $\mathrm{O}$ autor procura identificar quais seriam estes padrôes éticos de funcionamento dos operadores da justiça, assim como as consequências da ausência de discretion e accountability.

Os demais trabalhos situados nesse âmbito de problematização destacam, entre outras coisas, as permanências de um legado autoritário, que marcaria tanto a sociedade quanto a atuação do Estado, o qual atuaria na área penal pela lógica do extermínio do inimigo (FREIXO; SERRA; MEDEIROS, 2012). Ou, de outro lado, apontando as novidades de um contexto marcado pelas mudanças promovidas pela globalização e pela hegemonia neoliberal no capitalismo tardio, trazendo elementos novos para a compreensão da relação entre vitimizaçáo, medo do crime e insegurança social (BITTENCOURT; DADALTO, 2016). Trata-se, de qualquer modo, da recepção brasileira dos conceitos de punitivismo, encarceramento em massa, estado de exceção, estado punitivo e combate ao inimigo, sendo incorporados no sentido de reforçar permanências autoritárias que já estavam presentes.

Pastana (2013) entende que haveria uma nova característica no contexto brasileiro contemporâneo, que seria o crescente investimento no combate ao crime pelos governos democráticos, produzindo a figura do "estado punitivo" e uma ambiguidade entre democracia e autoritarismo. São utilizados referenciais diversos, como Wacquant, Garland, Christie, Bauman e Agamben, para sustentar $o$ argumento de que essa forma de estado teria despontado no Brasil nos últimos 30 anos como forma hegemônica de controle social.

A tese de Odon (2013), defendida no doutorado em sociologia da Universidade de Brasília (UnB), através da análise de textos de leis, discursos e pareceres de parlamentares e conselheiros de Estado, comentários de juristas, textos da imprensa, obras escritas e anotaçóes de viajantes estrangeiros da época do Império, sustenta que o sistema jurídico estatal brasileiro foi estruturado a partir da eleição de um inimigo da ordem pública e do papel central desempenhado pelo direito penal. O autor sustenta que o ordenamento jurídico foi moldado principalmente para marcar e normalizar o escravo liberto e o pobre ocioso, camadas sociais consideradas perigosas no plano político-social e supérfluas no plano econômico, lançando mão de uma técnica de poder de controle da presença social e da circulação dessas pessoas. A conclusão geral é de que a necessidade de controle sobre escravos libertos e pobres ociosos teria levado à criaçáo de um aparato burocrático racional-legal voltado para a repressão, que tinha na linguagem da pena o único diálogo possível entre o Estado e a sociedade, e que persiste até os dias de hoje no imaginário social.

A tese de Menezes (2015), defendida no Programa de Pós-Graduação (PPG) em ciências sociais da Pontifícia Universidade Católica de São Paulo (PUC-SP), analisou a relaçáo entre a cidadania e o direito penal no Brasil. Examinam-se os mecanismos de suplício, a algema e, por fim, a tornozeleira eletrônica, considerando-os tecnologias de poder do Estado que exercem ação direta sobre os corpos dos indivíduos julgados infratores da lei. O estudo sustenta a necessidade da 
adoção de políticas de segurança de mínima intervenção penal, respeitando-se, sobretudo, a dignidade do corpo humano e efetivando práticas de cidadania no campo penal.

\section{Política criminal e justiça penal}

Um segundo conjunto de trabalhos dá conta do tema da política criminal, ou seja, das escolhas realizadas no processo legislativo para configurar e orientar os processos de criminalização. Os trabalhos sobre esse tópico procuram avaliar o impacto das escolhas legislativas sobre o funcionamento da justiça penal, analisando, do ponto de vista quantitativo, as tendências relacionadas às taxas de encarceramento $e$, do ponto de vista qualitativo, as mudanças institucionais e os padróes de tomada de decisáo a partir das mudanças legais.

Em um trabalho que procurou relacionar as políticas de segurança pública nos governos Lula e Dilma com as escolhas de política criminal realizadas no período e as taxas de encarceramento, Azevedo e Cifali (2015) apontam a contradição entre o crescimento ininterrupto do número de presos provisórios e definitivos, e as definiçôes programáticas do Governo Federal. Os autores indicam os principais impasses e obstáculos para uma reversão dessa tendência de crescimento do encarceramento, assim como para a implementaçáo de um novo modelo de prevençáo ao crime, considerando que mudanças legais importantes ocorreram no sentido de frear a utilização abusiva do encarceramento em massa, como a Lei $n^{\circ} 12.403 / 11$, das cautelares no processo penal.

Especificamente sobre o impacto da política de drogas sobre o sistema de justiça criminal, Marcelo Campos produziu uma tese de doutorado (2015b) e um artigo que sintetiza os resultados da pesquisa (2015a). $\mathrm{O}$ autor apresenta dados quantitativos sobre a criminalização dos indivíduos no sistema de justiça criminal relacionada a drogas na cidade de São Paulo entre os anos de 2004 e 2009. Em 2006 entrou em vigor a chamada Nova Lei de Drogas. $\mathrm{O}$ autor analisa o perfil social dos indivíduos envolvidos nos delitos de drogas registrados em dois distritos policiais da capital paulista, buscando com isto compreender as práticas estatais na administração de conflitos. Conclui que "tais políticas e práticas diferenciam os ilegalismos, acionando desigualmente os mecanismos de estigmatizaçáo de acordo com o status, o grupo e a classe social de cada indivíduo incriminado por drogas em São Paulo" (Ibid., 2015a).

Com o mesmo foco, na cidade do Rio de Janeiro, Frederico Mendonça Filho (2013) discute o funcionamento do sistema de justiça criminal a partir dos desdobramentos de um caso de flagrante de "tráfico de drogas", que depois se transforma em "uso de drogas".

Ainda sobre o tema da política de drogas e seu impacto no sistema de justiça, Ribeiro, Rocha e Couto (2017) investigaram como as Varas Criminais de Tóxicos da cidade de Belo Horizonte aplicam a Lei de Drogas (Lei $n^{\circ}$ 11.343/06). Levando em conta as limitaçóes dos registros oficiais, os autores póem em questáo os limites e as possibilidades de estudo de trajetórias judiciais dos acusados a partir do banco de dados do Tribunal de Justiça de Minas Gerais (TJMG), referente a todos os procedimentos enquadrados na Lei de Drogas e encerrados na capital, entre 2008 e 2015. Verificaram que as Varas de Tóxicos funcionam como justiça em linha de montagem, especialmente nos casos iniciados por flagrante, ainda que isso signifique supressão de direitos do acusado. Segundo os autores, os dados do TJMG confirmam a tendência de redução do encaminhamento judicial de casos de porte de droga para uso pessoal, dando lugar à prevalência do tráfico de drogas. Os casos de tráfico de drogas são processados mais rapidamente que os de homicídio intencional, sendo que o flagrante 
tem um peso determinante nessa equação de tempo, reduzindo em mais de $50 \%$ o intervalo entre a distribuição e a baixa do processo.

Os resultados desse artigo indicam que o formato do fluxo do tráfico de drogas não é um funil, com muitas ocorrências registradas na polícia e poucas processadas e punidas na justiça, mas um cilindro, já que quase tudo que entra no sistema de justiça criminal, especialmente por meio do flagrante, tende a ser processado e sentenciado rapidamente (Ibid.). Essa constatação indica o enorme poder que a ação policial tem de criar a distinção entre traficantes e usuários, determinando tratamentos judiciais e sançôes muito distintas. Os acusados por tráfico têm processamento rápido, acelerado ainda pelo flagrante ou pela presença de mais de um registro pelo mesmo crime, compondo exemplos de como a "justiça em linha de montagem" funciona.

A tese de Edimar Rodrigues (2016), defendida no doutorado em sociologia da Universidade Federal de Pernambuco (UFPE), analisa, a partir das percepçóes dos legisladores, o que há de comum e de diferente nas experiências punitivas da modernidade tardia no Brasil e em outros países, especialmente Estados Unidos e Grã-Bretanha. Buscando relacionar as mudanças socioeconômicas e culturais com o surgimento de uma "nova cultura punitiva” denominada de punitivismo, segundo a obra de David Garland, a análise indica expressóes de punitivismo nas práticas do sistema penal brasileiro, de modo semelhante às experiências de Estados Unidos e Grä-Bretanha a partir dos anos de 1990, com a edição da lei dos crimes hediondos. Em oposição a esse rigor punitivo, atua também "uma vertente política que prioriza as medidas ressocializadoras, a prevenção (social e situacional) e as penas alternativas à prisão" (Ibid., p. 6).

A tese de Renata Moreno (2013), defendida no doutorado em ciências sociais da Universidade Estadual de Campinas (Unicamp), discute a efetividade da proteção ambiental no Brasil, em que o direito penal está legitimado como mecanismo de controle, através da criminalização de condutas, deixando de ser um direito garantidor da liberdade individual, para atuar na gestão do risco mediante a adaptação do aparelho punitivo do Estado, flexibilizando conceitos e contrariando princípios constitucionais. Segundo a autora, isto representa um aumento da insegurança jurídica, ao invés de aumento da proteção, na medida em que opera flexibilização de conceitos e princípios constitucionais na tentativa de gerir riscos mediante um aparato criado para a punição individual. $\mathrm{O}$ direito penal, concebido como ultima ratio, acaba convertido em sola ratio.

Fernanda Vieira (2012), em tese defendida no doutorado em ciências sociais da Universidade Federal Rural do Rio de Janeiro (UFRRJ), abordou a criminalização da luta pela terra no Rio Grande do Sul. Utilizou como material empírico o dossiê elaborado pela Brigada Militar no ano de 2007, que buscava identificar os vínculos do Movimento dos Trabalhadores Rurais Sem Terra (MST) com as Forças Armadas Revolucionárias da Colômbia (Farc) na região Norte do Rio Grande do Sul, assim como a ação penal com base na Lei de Segurança Nacional (Lei no 7.170, de 14 de dezembro de 1983) e açóes civis públicas que objetivavam reduzir a atuação do MST, como também a deliberação do Conselho Superior do Ministério Público que propugnou pela extinção do MST. A autora entende que a ação penal é reveladora do cenário de crescimento dos discursos punitivos, marca da hegemonia neoliberal, com ampliação dos processos de criminalização da pobreza e dos movimentos sociais reivindicatórios, ao mesmo tempo em que está em linha contínua com o passado colonial de controle e submissão das classes populares por meio do estatuto penal.

Herbert Rodrigues (2014), em tese de doutorado defendida no PPG em sociologia 
da Universidade de São Paulo (USP), realiza uma análise genealógica das estratégias narrativas presentes no processo de criminalização da pedofilia no Brasil. O foco de análise foi a produção discursiva do Judiciário e da psiquiatria, que constituem objetividades sobre a pedofilia e buscam definir o sujeito pedófilo. $\mathrm{O}$ autor utilizou diversas fontes para identificar os discursos sobre a pedofilia no Brasil - e em outros países -, tais como textos históricos e teóricos das ciências humanas, uma bibliografia especializada sobre o assunto, manuais prescritivos de açóes de combate ao abuso sexual infantil, legislaçôes e a jurisprudência disponível no Tribunal de Justiça de São Paulo (TJSP). Foram ainda problematizadas as representaçóes sobre a criança e o sexo, os pânicos morais em torno das sexualidades dissidentes e a fabricação de subjetividades contemporâneas.

\section{Estudos de fluxo e de decisões judiciais}

Os estudos sobre fluxo de justiça criminal têm sido mais frequentes, embora ainda restritos a poucas cidades e tipos criminais. $\mathrm{Na}$ seleção aqui apresentada, trataram do crime de homicídio, embora façam referência a estudos mais abrangentes dos últimos 15 anos.

O artigo de Arthur Costa (2015) ressalta que a maioria dos trabalhos intencionou abordar a questáo da eficiência, isto é, a capacidade da justiça criminal de absorver e julgar os crimes ocorridos, avaliando os aspectos que influenciam na sua seletividade. O autor propóe avaliar a efetividade, isto é, a capacidade da justiça criminal de incidir sobre a ocorrência de crimes. Contrariando o que se verificou em estudos realizados em outros locais e épocas, Costa relata uma alta capacidade de elucidação dos crimes de homicídio ocorridos no Distrito Federal em 2004. Mas a alta elucidação de autoria, a presença de laudos técnicos nas investigaçóes e a presença de testemunhas de fatos em uma quantidade significativa de casos $(75 \%$ das testemunhas dos inquéritos analisados trouxeram informações sobre os fatos) não necessariamente resulta em punição dos responsáveis pela morte violenta. Com esses dados, o artigo coloca em questáo o discurso de que a impunidade dos crimes violentos seja decorrente de ausência de recursos para as polícias.

Segundo Arthur Costa (Ibid.), 70\% dos inquéritos policiais do ano analisado tiveram a autoria elucidada (o que destoa do padráo relatado em outros estudos). Mas apenas 32\% das denúncias feitas pelo Ministério Público resultaram em condenaçôes, o que obriga a deslocar o olhar para o que acontece nessa instituição, no sentido de avaliar as descontinuidades no processo de acusação e o baixo número de acusações bem-sucedidas, num ambiente cultural e organizacional descrito em outras pesquisas como punitivista.

A pesquisa relatou haver muitas trocas de operadores durante o andamento dos casos, o que resulta em divergências de atuação dos promotores no mesmo processo criminal e é apontado como motivo da ineficiência na punição de mortes violentas, ao lado de denúncias realizadas sem provas suficientes para a condenação e desconfiança da lisura dos procedimentos da investigação policial (Ibid.).

Ribeiro, Machado e Silva (2012b) revisaram os estudos de fluxo da justiça criminal, especialmente aqueles que abordaram o processamento do crime de homicídio, para discutir as metodologias empregadas nesses estudos e ressaltar as diferenças de resultado obtidas. Os autores enfocaram o estudo comparado entre os tempos da justiça criminal utilizando os dados dos Tribunais de Justiça de São Paulo e Rio de Janeiro, mostrando que a contagem do tempo médio pode ocultar determinados casos que são muito demorados. Além disso, excluir da amostra os casos que não foram ainda encerrados também altera as 
conclusôes dos estudos, porque oculta o viés de casos que nunca vão a julgamento e cujo tempo de tramitação se arrasta por anos a fio. Assim, há casos que tramitam num tempo bastante próximo do estabelecido pelos lapsos descritos na legislação processual, enquanto outros se arrastam no tempo.

Embora considerem que o tempo de tramitação de um caso precise combinar critérios de justiça com critérios de celeridade, um tempo de tramitação excessivo acaba por comprometer a organizaçáo dos tribunais com uma espécie de "passivo" de processos que nunca encontram termo - o que náo necessariamente decorre do tempo utilizado pela defesa do acusado para garantir um litígio justo (Ibid.).

Os autores (Ibid.) propóem que os estudos de fluxo procurem utilizar as metodologias de "estudos de sobrevivência" e calculem variados tipos de medidas (como média e mediana, diferenciando a análise dos casos encerrados daqueles que náo encontraram termo) a fim de compreender melhor os significados organizacionais da celeridade ou da morosidade no tratamento dos crimes de homicídio. Esses termos podem estar relacionados a processos de seletividade judicial que ainda não foram bem apreendidos pelos estudos já realizados.

Por fim, destacam a enorme dificuldade em obter dados sobre a justiça criminal, posto que as bases oficiais não se encontram disponíveis aos pesquisadores, não são construídas com categorias padronizadas e náo existe uma disposição organizacional em apresentar dados sobre a produção judicial como item indispensável da transparência (Ibid.).

Em outro artigo, Ribeiro, Machado e Silva (2012a) avaliaram alteraçóes legislativas recentes no Código de Processo Penal que ampliaram as garantias de direitos humanos dos acusados em sucessivos procedimentos do processo penal. Analisaram julgados de 2008 a 2009 a fim de verificar como a lei em abstrato foi aplicada na prática, já que nem sempre os efeitos esperados por alteraçóes legislativas se concretizam quando aplicados pelos operadores, que interpretam a lei de acordo com concepçôes jurídicas distintas. Concluíram que as alteraçóes ampliaram a sintonia das leis penais com a Constituição Federal no que tange ao respeito aos direitos humanos. Enfatizam o grande papel dos juízes na interpretação das leis, os quais operam em uma cultura jurídica que consagra a supremacia do interesse do Estado sobre os interesses das partes.

A tensão entre demandas de celeridade e demandas do devido processo legal foi analisada na tese de Carlos Oliveira (2012), da pós-graduaçáo em sociologia da UnB, como tensão entre eficientismo e garantismo penal. Ao estudar práticas cotidianas em uma vara criminal, em 2011, no Distrito Federal, o autor observou estratégias de ação e acordos informais estabelecidos entre atores e organizaçóes da justiça criminal. $\mathrm{O}$ autor conclui que a tensão por eficiência e celeridade desloca os objetivos institucionais para a gestão dos meios, em detrimento dos fins de distribuir justiça.

$\mathrm{O}$ julgamento de crimes políticos durante as ditaduras militares no Brasil e na Argentina foi objeto da tese de Cleuber Souza (2015), realizada no Programa de Estudos Comparados sobre as Américas da UnB, enfocando a relevância da esfera jurídica nos regimes autoritários. Foram analisados processos judiciais sobre crimes políticos cujos principais acusados eram adversários e dissidentes políticos dos governos autoritários nos dois países. A conclusão foi que, no Brasil, o modelo autoritário tendeu ao recrudescimento da repressão com a suspensão do uso do habeas corpus para os acusados de crimes políticos após o Ato Institucional no 5 de $1968 . \mathrm{Na}$ Argentina, o uso do habeas corpus náo foi suspenso. Foram analisadas as decisóes proferidas nos habeas corpus para observar como o ordenamento jurídico foi utilizado para legitimar o exercício autoritário do poder. 
Entre as teses, estudos sobre homicídios e tribunal do júri também tiveram lugar. Defendida no PPG de sociologia da Unicamp, a tese de Cássia Garcia (2013) procurou abordar mecanismos sistemáticos de destruição de vidas humanas que existem no interior de um contexto de valorização social da vida saudável. Utilizou processos judiciais e inquéritos policiais sobre homicídios ocorridos em São Paulo em 1990 como fonte. A autora apontou a existência de ciclos de violência, nos quais a morte violenta decorre de circunstâncias que não derivam das condiçóes subjetivas de infratores e vítimas de um crime. Observou a inoperância das instituiçóes estatais - incluindo investigação policial e justiça criminal - para evitar mortes violentas, romper o ciclo de vingança e proteger a vida, nas quais se verifica a persistência de padróes institucionais abusivos.

Tema semelhante foi tratado pela tese de Flávia Santos (2016), que enfocou os processos cotidianos da investigação de homicídios em cidades fluminenses. Realizado no PPG de Antropologia da Universidade Federal Fluminense (UFF), o estudo se orientou para as técnicas e moralidades acionadas pelos agentes da investigação policial que constroem a verdade sobre a morte e os mortos. Considera-se o contexto em que apenas 6\% das mortes violentas são julgadas pela justiça criminal, o que se atribui à ineficiência da investigação. A pesquisa procurou entender como uma repartição burocrática policial relaciona sujeitos, coisas e fatos para constituí-los como homicídios.

O trabalho de Tiago Eli Passos (2013), defendido na área de antropologia da UnB, abordou três casos julgados pelo Tribunal do Júri no Distrito Federal, voltando a atenção para processos que conectam lei e vida, compreendendo o júri como espetáculo em que se relacionam distintas ordens normativas, nem sempre compatíveis ou conciliáveis.
Ainda sobre o tema da investigação criminal, Vitor Richter (2016), do PPG de antropologia social da Universidade Federal do Rio Grande do Sul (UFRGS), tratou da introdução no Brasil da tecnologia de análise de DNA em investigaçóes criminais, a partir da regulamentação e da recepção de bancos de perfil genético doados pelo Federal Bureau of Investigation (FBI), dos Estados Unidos. A pesquisa desenvolveu-se para compreender como na prática se realizam as mediaçóes entre tecnociência, direitos, cidadania e políticas de segurança, e quais são as implicações técnicas, éticas e políticas das decisóes tomadas neste processo.

A evolução histórica dos crimes e os atributos demográficos de réus e vítimas foi objeto da tese de Celso Aoki (2014), defendida na pós-graduação em sociologia da Universidade Federal do Paraná, utilizando como fonte o banco de dados de autos criminais do fórum de Londrina, entre 1934 e 1970. Nesse período de rápida urbanizaçáo, tipos sociais como ladróes, vagabundos, pobres e prostitutas são os principais protagonistas do conflito social apreendido pela ação policial e pela justiça criminal. $\mathrm{O}$ autor conclui que o Estado assumia papel preponderante para assegurar o monopólio da violência.

O artigo de Pedro Brocco (2016) avaliou a implementação da Lei de Medidas Cautelares em varas criminais do Rio de Janeiro, entre 2011 e 2012. Constatou o aumento de 10\% das fianças arbitradas em sede policial naquele período, a partir da vigência da lei, acompanhando um aumento proporcional de concessão de liberdades provisórias. $\mathrm{O}$ autor procurou correlacionar o aumento de aplicação de fianças a dados relativos ao desempenho da economia do país no período, como taxa de desemprego e operaçóes de crédito. Dessa forma, explora a relação entre a interpretação das leis, a concessão da liberdade provisória durante o processo e o aumento da sensação 
de confiança e otimismo, considerando que as condiçóes de eficácia da lei são efeitos de variáveis exteriores ao plano normativo, especialmente os indicadores econômicos.

Alessandra Prado e Danilo Schindler (2017) realizaram pesquisa sobre as dificuldades existentes para a desinternação de pacientes dos Hospitais de Custódia e Tratamento Psiquiátrico, com pesquisa empírica na Bahia. Concluíram que a aplicação das medidas de segurança segue a lógica da internação como regra, em descompasso com o modelo de atenção à saúde mental consagrado na Lei de Reforma Psiquiátrica, chamando a atenção para a urgência da adequação do tratamento dos infratores com transtorno mental, que atualmente viola a referida lei e dificulta a desinternação e a reintegração dos pacientes à vida em liberdade.

\section{Operadores judiciais e instituições}

Outro conjunto de estudos investiga as concepçóes e representaçóes sociais expressas pelos operadores do sistema penal, bem como analisa a configuração das instituiçóes que dele fazem parte, o relacionamento entre atores, fricçóes, disputas de práticas, saberes e posiçôes.

Em dimensão comparada, Geraldo e Barçante (2017) analisaram as relaçóes entre polícia e Ministério Público no Brasil e na França, comparando dados obtidos em suas pesquisas de campo. Observam que as instituições têm sentidos diversos nos dois países. Enquanto na França transparência e cooperação na administração da justiça produzem confiança entre os atores, no Brasil há opacidade na produção das peças e disputa institucional. Os resultados corroboram o que tem sido apontado por estudos sobre processamento de homicídios e investigaçóes criminais a respeito das especificidades da justiça criminal no Brasil.

O artigo de Machado e Porto (2016) refere-se ao estudo do processamento de homicídios na Área Metropolitana de Brasília. Baseado em pesquisa das representaçóes sociais dos operadores da justiça, o trabalho destaca a percepção de ineficiência da justiça criminal para os crimes de homicídio, aliada à percepçáo de abandono da população e das instituições estatais pelo poder público. Nas entrevistas e nos grupos focais com peritos criminais, delegados de polícia civil, promotores e juízes, foram enfatizadas as disputas entre as organizaçóes que participam da divisão de trabalho jurídico-penal. Acusaçóes mútuas e dirigidas ao governo estadual deram a tônica da avaliação dos operadores quanto ao fluxo. Peritos criminais dirigem críticas à ausência de relevância dos laudos técnicos na fase judicial. O Ministério Público foi retratado como uma instituição de recursos abundantes, materiais e institucionais, mas pouco engajada em operar judicialmente para a melhoria das condiçôes de trabalho de peritos e policiais. Os promotores, por sua vez, abordaram a escassez e as deficiências institucionais em todos os serviços públicos da regiáo metropolitana de Brasília, cujas consequências rebatem no sistema de justiça criminal. Também observam a precariedade de suas condiçóes de trabalho, com sobrecarga e ausência de investigaçóes criminais de qualidade para subsidiar sua própria atuação. Observam precariedades no trabalho de peritos, juízes e nas condições de defesa dos réus, ainda que considerem a atuação dos juízes como menos trabalhosa do que a sua. Os juízes, por sua vez, diante da precariedade também relatada, aderem a visóes punitivistas, considerando a fixação de penas altas para os réus que vão a julgamento um ato simbólico importante para fazer frente contra a impunidade da maioria dos homicídios e para evitar que os réus presos voltem a cometer crimes durante o período da pena. Enfatizam a função retributiva da pena, mais do que a finalidade de reabilitação do condenado.

Os autores concluem que as representaçóes sociais dos operadores judiciais 
pesquisados indicam o compartilhamento de uma visão de que "nada funciona", não havendo soluçôes viáveis para os problemas levantados no curto prazo. $\mathrm{Na}$ esteira dessa percepção, reforça-se que o número de homicídios é elevado em razão de "acertos de conta", isto é, situaçôes em que "bandidos matam bandidos", o que tornaria menos relevante a ausência de intervenção da justiça criminal sobre esses casos (Ibid.).

As representaçóes dos operadores do sistema de justiça criminal também foram abordadas na tese de Giane Silvestre (2016), defendida na pós-graduação em sociologia da Universidade Federal de São Carlos, cujo objetivo foi compreender como as instituiçôes e os operadores estatais do controle do crime são afetados pela emergência das novas formas de organizaçáo do crime, especialmente do Primeiro Comando da Capital (PCC), por meio de entrevistas com policiais civis e militares, delegados, promotores e juízes em diversas cidades do interior paulista e da capital. Temas como controle de tráfico de drogas, mudanças na condução da investigação criminal, dificuldades estruturais e disputas interinstitucionais no fluxo do sistema de justiça foram tratados. Foi construída uma tipologia das representaçóes sociais dos operadores sobre a relação entre Estado e crime. A primeira delas entende que o Estado fez uma opção política diante do surgimento e da consolidação do PCC, na qual as açôes de controle do crime são negociadas em acordos mais ou menos velados, em que as atividades criminais geram insumos para as açóes dos operadores do controle do crime. A segunda linha das representaçóes dos operadores seria a da leniência do Estado diante do PCC, na qual entendem que o seu fortalecimento só foi possível diante da lentidáo do Estado para enfrentá-lo. $\mathrm{O}$ terceiro conjunto de representaçóes seria o do fracasso do Estado, marcado pela ausência de diretrizes institucionais e pouca articulaçấo entre as diferentes instituiçôes estatais de controle da criminalidade, no que se ancoraria a legitimação das açôes violentas dos agentes estatais. A autora conclui que conflitos e disputas já existentes entre as instituiçóes tornam-se mais acirradas diante do fortalecimento do PCC, o que leva cada instituiçấo a desenvolver suas táticas de açấo no controle do crime.

Alexandre Rocha (2016) abordou a relação entre moral e direito nos processos judiciais envolvendo crimes contra o patrimônio em Montes Claros (MG), em tese de doutorado em ciências sociais da Universidade do Estado do Rio de Janeiro (Uerj). Avaliou, a partir da investigação realizada sobre as práticas profissionais dos atores do sistema de justiça criminal, a influência dos conceitos morais e sociais nas decisóes dos agentes jurídico-policiais responsáveis pela investigação, denúncia, defesa e pelo julgamento dos suspeitos de cometerem crimes contra o patrimônio naquela cidade.

Dayana Costa (2015), analisando as origens sociais, carreiras e representaçóes de juízas no Maranhão, aborda em sua tese um tema muito mais amplo do que esta revisão abrange; contudo é bom pontuar que seus resultados apontam a capacidade coercitiva da magistratura sobre a tomada de posiçâo dos agentes, a formação de seus esquemas de percepção, suas preferências e como concebem o papel de juiz e as relaçôes de gênero no interior da instituição. Essa tese foi defendida no doutorado em ciências sociais da Universidade Federal do Maranhã.

A tese de Marília Melo (2016), das ciências sociais da Uerj, acionou a antropologia das emoçóes para estudar a experiência da decisão judicial envolvendo direitos humanos, em especial de populaçóes LGBT, em relação aos magistrados. A partir de entrevistas, Melo abordou as dimensões morais e afetivas na experiência de decidir. Os resultados apontaram reflexóes sobre as concepçóes dos operadores da justiça sobre o processo de decidir, que a 
autora chamou de "etnopsicologia jurídica", bem como para a percepção de mudanças de sensibilidade na construção dos direitos humanos e nos sentimentos de justiça.

Em perspectiva histórica, Rolim e Rodrigues (2013) estudaram os autos do processo sobre o assassinato de um homossexual em um tribunal da Capital da República em meados do século XX. Ressaltamos que a cultura jurídico-penal reproduziu padróes socioculturais ocidentais, em que são condenados o prazer e as formas de senti-lo. Mesmo não sendo crime, a homossexualidade é reprimida por meio da legalidade processual.

Ainda no que tange às representaçôes implícitas na cultura técnico-jurídica, Vera Almeida (2012) relata como as representaçóes sobre a legalidade interferem na efetividade da distribuição da justiça e na concretização do modelo de cidadania previsto na Constituiçáo de 1988, já que o ordenamento das leis penais é anterior a ela. Na medida em que o direito é também uma criação dos operadores, a análise da jurisdição enfatizou as representaçôes contidas na justificativa judicial para a criação de uma pena não prevista em lei nos Juizados Especiais Criminais (JECrim) do Rio de Janeiro. Nas decisões examinadas, verificou-se uma ideologia que tende ao aniquilamento da cidadania do jurisdicionado, por meio de representaçóes negativas sobre ele (estigma de delinquência e inferioridade) e de estratégias inquisitoriais e antidemocráticas. A autora conclui que o dilema da jurisdição brasileira é a necessidade de pessoalizar a aplicação da norma, justificando-se a todo o momento diante do paradoxo entre os modelos igualitário e hierárquico, que opera a cultura jurídica.

O artigo de Adalmir Leonídio (2016) mobiliza os conceitos de criminalizaçáo dos movimentos sociais, argumentando que a justiça criminal é peça importante no tratamento da divergência política pelo enfoque do inimigo, ao analisar um conjunto de açôes penais movidas contra militantes do MST na regiáo do Pontal do Paranapanema, no estado de Sáo Paulo. As representaçôes dos operadores jurídicos transmitidas nas peças minimizam a dimensão política dos conflitos agrários e desconsideram que as demandas sejam afeitas aos direitos humanos. Segundo o autor, o enfoque do inimigo interno distancia a justiça criminal de uma visão de Estado social de direito e reforça o predomínio do Estado penal.

\section{Violência contra a mulher}

Os estudos sobre a atuação da justiça criminal nos casos de violência contra a mulher se tornaram muito mais frequentes nos últimos anos, e a maioria deles procura avaliar a implantação e a efetividade da Lei Maria da Penha, de 2006, bem como discutir potencialidades e limites da justiça criminal para administrar os conflitos violentos de gênero.

Fernanda Vasconcellos (2015), em tese defendida no PPG de ciências sociais da UFRGS, avalia que a Lei Maria da Penha (Lei $\mathrm{n}^{\circ} 11.340$, de 7 de agosto de 2006) emerge no contexto de democratizaçáo da sociedade brasileira, ao qual corresponde a ampliaçáo do reconhecimento de direitos. A lei trouxe um novo desafio ao Poder Judiciário ao estabelecer a unificação de competências jurídicas para tratar dos conflitos violentos familiares. O objetivo era administrar os conflitos de modo mais ágil e reduzir os danos das partes. Contudo essa pesquisa no Rio de Grande Sul indicou a existência de fortes disputas entre diferentes âmbitos do campo jurídico, ordenado em estrutura judicial rígida. Os dados indicaram que o Judiciário resiste à unificação das competências criminal e cível na administração das violências familiares e domésticas, tendo emergido disputas entre JECrim, Varas Criminais, Varas de Infância e Juventude, Varas de Família e Sucessóes e Juizados Especiais de Violência Doméstica 
e Familiar contra a Mulher a respeito da competência para administrar os conflitos. Para além de uma disputa interna do campo jurídico, a autora identifica conflitos morais sobre a delimitação do conceito de família, que é restrito às relaçóes já formalizadas. A garantia dos direitos das mulheres vítimas de violência doméstica fica subordinada à lógica burocratizante e ao reconhecimento limitado de configuraçóes familiares, o que contraria a efetivação das expectativas democratizantes que ensejaram a implantação da lei.

Um artigo da mesma autora (Idem, 2013) argumenta que os conflitos violentos contra a mulher possuem especificidades que os mecanismos da justiça penal não estão aptos para considerar. Observando um conjunto de serviços de atendimento, a autora conclui que a lógica penal coloniza todos os demais mecanismos voltados para a prevenção da violência e a garantia de direitos. Considera que a opçấo pelo endurecimento penal é característica do atual contexto de demanda punitiva por parte dos movimentos sociais, contudo trata-se de uma adesão ao populismo punitivo e a um modelo de Estado regulativo, que náo carrega em si potencial para garantir a igualdade de gênero e prevenir a violência.

A tese de Andrea Reginato (2015), defendida no PPG em sociologia da Universidade Federal de Sergipe, avaliou a relação paradoxal entre direitos humanos e puniçáo na semântica dos movimentos sociais na elaboração da Lei Maria da Penha. Ao propor um rígido modelo punitivo para garantir e concretizar direitos, o caráter progressista da lei convive com a lógica da pena, impedindo a ocorrência de inovaçôes "humanistas" no sistema de direito criminal e as alternativas ao processo penal convencional. Segundo a autora, essa opçáo, apoiada por amplos segmentos do movimento feminista, representaria um obstáculo ao desenvolvimento inovador de estruturas operativas no sistema de direito criminal, reforçando a racionalidade penal moderna, sem resolver antigos problemas no tratamento da violência contra a mulher.

Em pesquisa realizada em cinco capitais sobre o acesso à justiça das mulheres em situação de violência, Wânia Pasinato (2015) avaliou a efetividade da Lei Maria da Penha, observando a distância entre o que é preconizado pela norma e as práticas e rotinas profissionais e institucionais. Foram entrevistados 64 profissionais envolvidos com a aplicaçáo da lei. Os resultados apontaram a persistência de estereótipos de gênero orientando a conduta dos profissionais, criando situaçóes discriminatórias que limitam o acesso à justiça e o reconhecimento das mulheres como sujeitos de direitos.

Embora as realidades sejam diversas entre as cidades, foram relatadas dificuldades decorrentes da falta de investimento público em instituições para o atendimento. Foi muito enfatizada pela autora a deficiência em termos de formaçáo de recursos humanos para o atendimento da violência baseada no gênero. Há baixa especialização entre operadores do direito e profissionais dos serviços de atendimento, e há pouco domínio técnico e burocrático das questôes de acesso à justiça e das especificidades das mulheres em situaçâo de violência. Especialmente prejudicial à efetivação das finalidades da lei é a ausência de protocolos de atendimento, com regras institucionais a serem seguidas por todos os profissionais. A ausência de protocolos deixa o acesso à justiça e o reconhecimento de direitos condicionados a atitudes e valores pessoais de quem está à frente dos serviços de justiça e dos serviços sociais (Ibid.).

A partir da análise da Comissão Parlamentar Mista de Inquérito que investigou a violência contra a mulher, Carmen Hein de Campos (2015) aborda as instituições que compóem a rede especializada de atendimento à mulher em situação de violência, 
procurando observar os desafios envolvidos nas dimensôes preventiva e assistencial. Uma das constataçôes é que as redes são diversificadas, mais pessoalizadas que institucionalizadas e menos presentes nas cidades menores. Os serviços têm precária estrutura física e ausência de profissionais e estão despreparados para lidar com as mutaçóes do fenômeno da violência contra a mulher. Além de ser uma questão de recursos financeiros, trata-se de uma política criminal, pois a rede de serviços de assistência às mulheres em situação de violência é, segundo a autora, a aposta da Lei Maria da Penha para reduzir o protagonismo da perspectiva repressiva no enfrentamento à violência (Ibid.).

Visando esse debate, o filósofo José Rodrigo Rodriguez (2015) revisou estudos sobre o tratamento penal à violência contra a mulher, buscando identificar os principais problemas apontados pela literatura feminista das ciências sociais e as práticas alternativas possíveis. $\mathrm{O}$ autor reflete sobre como os movimentos feministas demandaram a juridificação das relaçóes de gênero no Brasil e sobre o peso dado ao direito penal como principal via de administração dos conflitos violentos. Volta-se a pesquisar formas de juridificação imaginadas - "utopias institucionais" - como alternativas ao tratamento penal, sem correr o risco de se reinscrever os conflitos violentos na esfera do privado e da reprodução de desigualdade e violência.

Segundo Rodriguez, o debate até então colocado no campo da política tem identificado a gramática do Estado de direito à gramática dos crimes e das penas: leis, tribunais, delegacias, vítimas, agressores e punição individual. Segundo o autor, as pesquisas sobre ineficiências e disfunçóes do tratamento institucional da violência contra a mulher recolheram evidências de que o tratamento penal, embora ajude a tornar público um problema vivido no privado, constrói uma narrativa que individualiza o problema da violência, punindo indivíduos e passando ao largo das "estruturas [que] reproduzem a dissimetria de poder que caracteriza as relaçóes de gênero" (Ibid, p. 321).

O autor conclui haver falta de clareza na literatura sobre a natureza e o papel dos organismos náo penais previstos na Lei Maria da Penha, como centros de referência, núcleos especializados e casas de abrigo, que comporiam a rede de serviços de atenção para mulheres em situação de violência. Além da constatação dos limites da forma penal, há pouca imaginação e experimentação sobre as institucionalidades com potencial de avançar no tratamento da violência para além da redução vitimizante-punitivista - o que seria uma pauta importante da pesquisa e do ativismo.

As formas de judicialização são também objeto do artigo de Theophilos Rifiotis (2015), que coloca em perspectiva a produção da justiça nos casos de "violência de gênero" em dois trabalhos etnográficos, um anterior e outro posterior à Lei Maria Penha, realizados em João Pessoa e Florianópolis. No primeiro, foram abordados os sentidos da "mediação policial" na Delegacia da Mulher, cujo trabalho de administração de conflito era muito mais abrangente do que a produção de inquéritos policiais, havendo um descompasso entre o registro de ocorrência e os casos efetivamente atendidos, que criava uma percepção negativa sobre o trabalho das delegacias nas próprias policiais e no movimento de mulheres. No segundo, foi observada a adoção do "perdão judicial" nas chamadas "audiências de ratificação". Na mediação policial é exercido um tipo de escuta que visa conciliação entre as partes. A perspectiva de um trabalho em série, em que os casos atendidos fazem parte de uma sequência de agressóes, é percebida como "enxugar gelo" ou "trabalho morto", na medida em que a criminalização clássica não era perseguida pelas "clientes". Em vez disso, notou-se o uso da delegacia como instância de 
controvérsia e arbitragem, donde não se pode considerar a polícia como simples correia de transmissão entre os conflitos de gênero e o campo jurídico.

$\mathrm{Na}$ análise dos casos de "perdão judicial" concedidos em processos de violência contra a mulher, verificou-se a recorrência de extinção do processo sem aplicação de pena, com o aval da vítima, instituto previsto no Código Penal e não mencionado na Lei Maria da Penha. Segundo o autor, essa forma de aplicação contraria as expectativas feministas que impulsionaram a criação da lei e só podem ser compreendidas no contexto de uma "cultura jurídica" que reforça certos estilos de julgar em funçấo do desempenho de papéis sexuais das partes envolvidas no processo e da defesa da instituição familiar. O campo jurídico é visto como um espaço em que se prolonga a luta social, capturada pela semântica jurídica, sem nunca a ela se reduzir (Ibid.). É um espaço em que leis e institutos jurídicos são apropriados pelos atores sociais, de modo decisivo para a avaliação da "efetividade" das mudanças normativas. Nessa avaliação, os próprios estudos da produção da justiça são parte das lutas e da construção das agendas políticas.

Também sobre Santa Catarina, a tese de Isis Garcia (2016) defendida na pós-graduação em antropologia social da Universidade Federal de Santa Catarina analisou audiências do juizado especializado e observou "ausência de direito" em audiências de ratificação e "excesso de direito em "audiências de instrução e julgamento", observando uma lacuna na produção da justiça, que só pode existir como aporia, não sendo, contudo, uma solução satisfatória.

O artigo de Daniel Simiáo e Luís Roberto Cardoso de Oliveira (2016) é sobre o tratamento judicial de casos de violência doméstica em cinco juizados especiais do Distrito Federal. Entre eles verificaram-se procedimentos e práticas distintas, o que produz consequências para a percepção de justiça dos atores envolvidos. A prática da suspensão condicional do processo é frequente e orienta a pesquisa para observar condicionantes extralegais que interferem no processamento dos casos de violência doméstica.

Segundo os autores (Ibid.), a criminação do ato é resultado de uma complexa dinâmica de interpretaçấo, sujeita às moralidades que operam na categorização da "violência" por parte dos atores. Representaçóes e valores morais externados por delegados, promotores e juízes marcam a construção do sentido do ato como crime. Na medida em que a linguagem jurídica pode afastar os sentidos originais dos "fatos" vividos pelas partes como violência, a dimensão criminal do conflito pode ser reduzida, dando ensejo à suspensão condicional do processo. Embora tenha ocorrido na maior parte dos casos, a suspensão do processo não significa necessariamente impunidade e agravamento do conflito.

Nas audiências em que se monta a suspensão condicional do processo, Simiáo e Oliveira (Ibid.) observaram o predomínio de uma dinâmica conciliatória como parte da ação inquisitiva da autoridade estatal sobre um sujeito cuja conduta deve ser corrigida e constantemente observada.

Em um sistema judicial marcado pela lógica inquisitorial e pela figura da autoridade distante das partes, e também pela figura dos atores políticos que defendem os direitos das mulheres, concluem os autores, a judicialização é uma estratégia arriscada. A atuação dos juízes nas audiências de suspensáo condicional do processo pode ter um efeito de coerção sobre os agressores, no contexto de uma sociabilidade hierárquica. Contudo é um mecanismo totalmente dependente de uma autoridade judicial vertical e inquisitorial, postura que parece pouco alinhada a um projeto de questionamento de representaçóes hierárquicas de gênero (Ibid.). 
Izis Reis (2016) dedicou sua tese à pesquisa sobre o Ministério Público nos casos de violência doméstica contra mulheres, no Distrito Federal, em trabalho defendido no PPG de Antropologia da UnB. Ela observa que a complexidade das relaçôes de gênero, que envolvem afeto, convivência familiar e desigualdades, exige uma atuação jurídica diferenciada, com necessidade de diálogo com outras áreas do conhecimento. Para responder a isso foram criadas equipes multidisciplinares. A pesquisa analisou conflitos e diálogos entre os campos profissionais no Ministério Público (direito, psicologia e serviço social), nos quais foi verificada a tensão de representação do sujeito: como indivíduo plenamente autônomo e liberal ou como sujeito relacional, imbricado em contextos concretos. Conforme conclui a autora, a efetividade de coibir e prevenir a violência doméstica e familiar depende da democratização do Ministério Público, com equalizaçáo entre os distintos saberes, combinando os limites da lei penal como o cuidado proposto pelas equipes psicossociais. Também é necessário a articulação entre sistema de justiça e órgãos executores de políticas públicas.

Em pesquisa sobre a compreensão das lutas pelo acesso ao campo jurídico na implementação da Lei Maria da Penha, Anna Christina Barbosa (2014) analisou as práticas e representaçóes sociais de ativistas do movimento feminista e de operadores do sistema de justiça em Juazeiro (BA) e Petrolina (PE) sobre rearranjos institucionais do Estado propiciados pela lei. Na tese, defendida no PPG de ciências sociais da Universidade Federal do Rio Grande do Norte, a autora conclui haver inconsistências na atuação do sistema de justiça criminal e que o ativismo feminista acredita ser possível modificar paradigmas e garantir direitos por meio da prática política.

A pesquisa realizada em Vitória da Conquista (BA), para tese defendida na pós-graduação em ciências sociais da PUC-SP, também avaliou a efetividade dos aspectos criminais da Lei Maria da Penha. Luciana Silva (2014) concluiu que os efeitos são de cunho simbólico no contexto da cultura do expansionismo do campo penal, uma vez que entre 2006 e 2013 houve poucas sentenças condenatórias. A pesquisa se baseou em análise de processos judiciais e de outros documentos, além de entrevistas.

A tese de Fernanda Matsuda (2016), do PPG de sociologia da USP, abordou os dispositivos do sistema de justiça criminal para realizar a gestão de mulheres, de uma perspectiva como vítimas de crimes violentos, que demandam legislaçáo criminal para traduzir suas demandas, e de outra como autoras de delitos, às quais se voltam os mecanismos penais, em especial a prisão em flagrante. Na pesquisa realizada em São Paulo, utilizou-se abordagens qualitativa e quantitativa, enfatizando trajetórias individuais, com base em biografias judiciárias, para compreender as especificidades do encontro entre as mulheres e o sistema de justiça criminal. Matsuda encaminha a conclusão para pôr em evidência um continuum de violência que marca as vidas das mulheres.

$\mathrm{Na}$ pesquisa, identificamos artigos que se valem do estudo de leis e processos penais como fontes para o estudo das desigualdades de gênero. Nesses trabalhos o funcionamento da justiça criminal não é o objeto central da reflexão, mas esta é tangenciada pelo tema da criminalização e da política penal para lidar com a injustiça de gênero.

É o caso do artigo de Margarita Ramos (2012), que realiza o estudo de seis acórdáos do Tribunal de Justiça mineiro em que a justificativa da legítima defesa da honra foi mobilizada em processos de homicídio, entre 2000 e 2008. Conclui-se que o assassinato de mulheres é o ponto culminante de uma rede de violaçóes que se inicia na forma como as mulheres são retratadas pelo discurso como sujeitos inferiores, instintivamente agressores 
e passíveis de controle violento. Em quatro dos seis casos estudados o júri absolveu ou reduziu a pena, acatando a tese da legítima defesa da honra em casos de adultério. Nos demais, a defesa recorreu à tese para reverter a condenação.

Crimes passionais e as representaçóes de gênero envolvidas nos processos criminais, na literatura jurídica e em reportagens da imprensa foram abordados na tese de Antônio Carlos Conceição (2015), do programa de Estudos Interdisciplinares sobre Mulheres, Gênero e Feminismo da Universidade Federal da Bahia. O recorte empírico foram crimes ocorridos em Salvador, entre 1940 e 1980, mediante o qual o autor analisou as sensibilidades em torno da passionalidade. Ele conclui que as representaçóes predominantes reiteram a submissão das mulheres aos homens, o que tem sido objeto de lutas feministas para dar visibilidade à questão no espaço público.

Em perspectiva histórica, Flávia Castro (2015) recupera os discursos construídos sobre a mulher no direito criminal, em processos da comarca de Vassouras (RJ), entre 1860 e 1890 . Na tese do PPG de sociologia e Direito da UFF, a autora analisa o conjunto normativo do período, as opinióes doutrinárias e as representaçóes de crime nos tribunais e advogados. Castro percebe como eram traçadas as singularidades das mulheres nos processos e as visóes sobre diferentes papéis femininos, de vítima ou autora de crimes. Conclui que o discurso jurídico teve papel ativo na definição das realidades sociais, em conflito com outras concepções, podendo agravar ou amenizar a situação subalterna das mulheres no período.

Doze processos criminais sobre tráfico internacional de pessoas para exploração sexual, tramitados entre 1995 e 2012 em Goiás e no Ceará, são o material empírico que embasa a análise de Anamaria Venson (2017, 2015), da qual se concluiu que o combate ao tráfico internacional serve como técnica de combate à prostituição e às prostitutas. Uma ordem de saber anuncia que um dos empecilhos do combate ao tráfico de pessoas é que "as vítimas não se consideram vítimas". Assim, sob o argumento de proteger as mulheres, o que se está proibindo é a saída de brasileiras trabalhadoras do sexo do país. Flagrantes sensacionais armados em aeroportos internacionais levam à extração de "confissóes" das envolvidas sobre suas intenções de inserção no campo laboral sexual estrangeiro, deixando evidente que a prostituição ainda é socialmente associada ao ilícito, para o qual as mulheres seriam empurradas por vulnerabilidade, engano, tolice ou desvio moral. A recorrência e a homogeneidade destas práticas policiais indicam que a criminalização do tráfico de pessoas serve ao controle da prostituição.

Sobre assunto semelhante, a tese de Guilherme Dias (2014), da pós-graduação em antropologia social da Unicamp, enfatiza a articulação entre migração e segurança, demonstrando como os campos migratório e da justiça criminal tornaram-se inter-relacionados. $\mathrm{O}$ autor enfocou organismos internacionais, os quais atuam na intersecção entre migração e segurança/criminalidade, reapropriando retóricas dos direitos humanos. Conclui que a categoria "tráfico de pessoas" é utilizada para governar a migração e controlar as populaçóes.

Mobilizando teorias e conceitos psicanalíticos, Paula Penna e Fábio Belo (2016) consideram que a Lei Maria da Penha, ao transformar os crimes contra a mulher em crimes de ação penal pública incondiciona$\mathrm{da}$, torna o processo contra o agressor uma iniciativa do Estado, independentemente da vontade da mulher vítima da agressão. Os autores sustentam que esta perspectiva coloca o sujeito feminino em posição de subalternidade, cuja voz não pode ser ouvida. Com isso, uma dobra ideológica que trata a mulher como 
infantil e passiva é reforçada pela submissão do "modo de ser" da mulher ao "juiz salvador". Penna e Belo concluem pela necessidade de criar políticas públicas robustas, mediante uma rede de atendimento que fortaleça a resistência e a emancipação.

\section{Violência policial e tortura}

O tratamento da justiça criminal para os crimes cometidos por policiais, como mortes em decorrência de ação policial e tortura, foi tema de artigos e teses nos cinco anos pesquisados.

Lucía Eilbaum e Flavia Medeiros (2015) refletiram, a partir de dois casos que geraram repercussão, sobre criminalização do abuso policial e processos penais contra policiais, no Rio de Janeiro. Nos casos abordados, a ação foi entendida como "violência policial", contudo essa categoria nem sempre é adotada para descrever mortes cometidas por policiais, podendo ter várias significaçóes a depender do estatuto moral das vítimas. Num deles, a morte de um jovem negro despertou mobilização política e social após testemunhos que a qualificaram como violência e abuso policial. O outro trata da morte de uma juíza que acatou a denúncia e determinou a prisão de 11 policiais envolvidos em mortes. As autoras concluem que administração dos casos como crime dependeu das moralidades acionadas nos seus contextos específicos, e não da prevalência de uma sensibilidade legal que reforçaria a universalidade dos direitos humanos (EILBAUM; MEDEIROS, 2015).

Outro artigo abordou o processo relativo ao Massacre do Carandiru, ocorrido em São Paulo, em 1992, no qual 111 pessoas foram vítimas fatais da intervenção da Polícia Militar na Casa de Detenção. Luisa Ferreira, Marta Machado e Maíra Machado avaliaram a atuação do sistema de justiça nos processos criminais. Os crimes de homicídio estavam no limiar da prescrição, e os denunciados são policiais dos níveis mais baixos da hierarquia militar. Os réus de patente mais alta, denunciados por lesão corporal, tiveram os crimes já prescritos. O comandante da operação, o secretário de segurança pública e o governador náo foram formalmente acusados, e as açóes pelas quais poderiam responder já estariam prescritas. As pesquisadoras não puderam ter acesso a procedimentos disciplinares internos da Polícia Militar, trabalhando com a informação de que foram inexistentes. Os processos civis de indenização pelos danos materiais e morais foram concluídos integralmente somente para familiares de 26 das 111 vítimas. A Comissão Interamericana de Direitos Humanos da Organização dos Estados Americanos considera o Brasil responsável pela falta de investigação, processamento, punição e indenização de familiares, e seu relatório já existia há doze anos sem produzir consequências. Uma das recomendaçôes foi a de "descongestionar a população" detida, o que evoluiu em sentido contrário nos últimos 25 anos, em que cresceu vertiginosamente o número de presos. As autoras concluem que as instituiç̧óes judiciais não têm capacidade de reagir ao evento do Massacre do Carandiru, seja pela ineficácia da justiça criminal, seja pelas condiçóes objetivas e políticas referentes ao encarceramento e à atuação violenta da Polícia Militar, a despeito dos esforços de reflexão, narrativa, denúncia e construçáo de sentido sobre o evento por parte da sociedade civil (FERREIRA; MACHADO; MACHADO, 2012).

Sabrina Silva (2013) abordou em sua tese, defendida na pós-graduação em antropologia da UFF, a Auditoria da Justiça Militar no Rio de Janeiro, responsável pelo julgamento de policiais e bombeiros militares. A autora analisou como os agentes judiciais e militares estaduais interagem com as narrativas de conflito, com outros agentes profissionais e com as normas legais, e como são construídas e interpretadas as provas e as decisóes. Observou 
a hierarquização das narrativas conforme as classificaçóes do sistema de justiça e da própria polícia, concluindo que essa hierarquia é condicionante para que uma ação policial possa ser criminalizável.

A institucionalização da Justiça Penal Militar também foi analisada por José Lenho Diógenes (2017) na tese, realizada pelo PPG de sociologia da Universidade Federal do Ceará, em que a discute como um subsistema. Segundo o autor, as sequências de comunicaçôes sobre o crime militar produzem e reproduzem identidades de sentido, referências, valores, compartilhando uma racionalidade peculiar que faz parecer natural ao subsistema pontos de vista sobre o mundo, os quais definem o que será (e o que não será) compreendido como crime militar. A tese analisou mais de 2 mil acórdãos do Supremo Tribunal Federal e do Superior Tribunal de Justiça em que são discutidos crimes militares.

Outra forma de abordar a política criminal em torno da açáo policial é observar a elaboraçáo da lei contra a tortura no Brasil, de 1997. Mariana Possas (2015) analisou a relação entre o posicionamento político-ideológico e o sistema de direito criminal no processo de produção de leis penais. Concluiu que as distinções entre "conservador" e "progressista" que, em geral, qualificam as escolhas em matéria de direito penal, são variáveis quando está em jogo a distinção entre crimes "comuns" e crimes "contra a humanidade", como é o caso da tortura. Isso poderia ser atribuído à reprodução da racionalidade penal moderna pela prática política (POSSAS, 2015).

\section{Alternativas ao penal, alternativas penais}

O tema das alternativas penais se divide em: estudos sobre a aplicação, pelo Judiciário, das penas e medidas alternativas ao encarceramento; estudos sobre o funcionamento e as alternativas de controle punitivo criadas nos JECrim; e os estudos sobre a implantaçáo de programas de Justiça restaurativa no Brasil.

Souza e Azevedo (2015), utilizando a análise discursiva das motivaçóes indicadas nos projetos de lei que tramitaram no Congresso Nacional, mostram como as reformas despenalizantes, orientadas por ideologias emancipatórias e fomentadas pelos governos à esquerda, especialmente na América Latina, podem acabar aprisionadas às velhas estruturas do controle social, que reservam a inovação para certos grupos e certas práticas delitivas (aquelas mais frequentes nas classes abastadas), enquanto reservam a reprodução do controle social violento aos setores populares e menos favorecidos.

Os autores fazem um balanço cuidadoso das argumentaçôes que justificaram a ampliação da adoção de penas alternativas no Brasil (SOUZA; AZEVEDO, 2015). Em sua origem ela teria visado, em outras experiências históricas, à redução da aplicação da pena de prisão. Mas no Brasil o movimento é destoante: o número de penas alternativas aplicadas cresce juntamente com o número de presos. A análise dos autores dá conta de que as justificativas adotadas nos projetos de lei para o uso de penalidades alternativas à prisão estão baseadas numa divisão ontológica entre os cidadãos que são merecedores de penas brutalizantes e os que não o são. Trata-se quase sempre, no Brasil, de adotar políticas criminais com base em distinçóes ontológicas entre os merecem e os que náo merecem usufruir de direitos. E tudo indica que náo são argumentos que apelam para a diferença de gravidade entre os tipos de crimes, mas entre os tipos de pessoas que os cometem.

Com essas constatações empíricas, os autores deixam evidente a centralidade do debate sobre o controle social para o pensamento contemporâneo, como já haviam feito Michel Foucault e David Garland. O problema do 
controle social e da punição é uma questão que separa os sujeitos em constituiçóes ontológicas, que separa "nós" e "eles", questionando no seu cerne o discurso da modernidade igualitária e democrática (SOUZA; AZEVEDO, 2015).

Marcelo Berdet (2015), em tese de doutorado defendida no PPG em sociologia da UnB, sustenta haver um descompasso entre a compreensão das penas alternativas como uma sanção penal e o significado social que lhe é atribuído. Combinando métodos quantitativos e qualitativos, realizou análise de conteúdo em documentos produzidos pelas instituições diretamente envolvidas na execução das penas alternativas ou que politicamente atuam no sentido de fomentar o seu uso. Analisou também dados coletados sobre os cumpridores de penas alternativas no Distrito Federal até 2012. A conclusão é que essas sanções náo se desprendem do sentido da pena como punição imposta pela autoridade legal e, com isso, carregam consigo a dualidade de punir com o propósito de promover a justiça social e políticas públicas inclusivas.

Vera Almeida (2014) analisou as práticas de atualização do consenso e da verdade processual por meio da observação da aplicação de um instituto próprio dos JECrim: a transação penal. Por meio de pesquisa qualitativa em JECrim estaduais da Baixada Fluminense, baseada na interpretação dos discursos dos operadores jurídicos desses órgãos, na descrição etnográfica, na observação participante de suas práticas e na comparação desse material com o discurso legal e doutrinário, reflete-se sobre as garantias processuais próprias do Estado democrático de direito no sistema brasileiro.

Analisando a economia das trocas punitivas a partir de uma etnografia de JECrim, Carmen Fullin (2011), em tese defendida no PPG em antropologia social da USP, aponta que esses juizados são caracterizados pela rápida distribuição de punições não carcerárias, como prestação de serviços à comunidade e sançóes monetárias. A agilidade apoia-se na utilização de acordos estabelecidos entre promotores e suspeitos de crimes considerados leves, com a finalidade de evitar o processo judicial. A pesquisa também foi publicada em artigo (FULLIN, 2015).

Prudente (2012), em tese de doutorado defendida no PPG em sociologia da UnB, estudou a reestruturação do campo de gestáo de conflitos interpessoais no Brasil a partir da disseminação de suas práticas alternativas. Para examinar essa mudança e sua relação com a de Reforma da Justiça no país, a autora utiliza os conceitos de campo e de habitus de Bourdieu e a análise de redes sociais de atores da área. Conclui que as práticas alternativas trouxeram significativas mudanças para o campo de gestão de conflitos interpessoais, com a introdução de novos atores, alterando a dinâmica de poder estabelecida. O protagonista na disseminação das práticas alternativas no país foi o Poder Executivo Federal, sob a influência dos campos da política e da segurança pública. Embora amplamente disseminada, a ideologia das práticas alternativas restringe-se à esfera discursiva, enquanto as práticas ainda reproduzem uma perspectiva tradicional de gestáo de conflitos.

Analisando possibilidades a partir da experiência belga, Achutti (2015) apresenta o sistema de justiça restaurativa e demonstra como os mecanismos restaurativos interagem com o sistema de justiça criminal naquele país. $\mathrm{O}$ autor descreve as dificuldades iniciais enfrentadas, na década de 1990, e como estas foram superadas, lançando mão de entrevistas com mediadores e acadêmicos europeus. Em perspectiva crítica, Achutti projetou possibilidades para a adoção da justiça restaurativa no Brasil. Concluiu que a justiça restaurativa náo é apenas uma mudança de procedimento, mas uma mudança cultural que depende do rompimento com o paradigma do crime-castigo, 
da alteração da distribuição de poder entre os envolvidos (partes e operadores jurídicos) e da redefiniçáo de como os fatos legalmente classificados como delituosos são interpretados. Ao encontrar espaço para discussão de variáveis subjetivas (afastadas da justiça criminal como sentimentos irracionais), as partes que optam pelo sistema restaurativo tendem a dar maior credibilidade ao sistema de justiça, pois percebem que sua versão foi efetivamente considerada e discutida.

Juliana Tonche (2015), em tese de doutorado defendida no PPG em sociologia da USP, realizou uma análise de programas de justiça restaurativa que funcionam no estado de São Paulo. Através de pesquisa qualitativa, a autora conclui que essas iniciativas não estão rompendo com as lógicas do sistema de justiça comum, pois além de integrarem um quadro em que a justiça criminal continua sendo central, estão aumentando as possibilidades de expansão da rede de controle social, inaugurando configuraçóes inéditas de programas que mesclam o formal e o informal, saber leigo e expertise. Tonche sustenta também que a justiça restaurativa, a despeito de seu potencial transformador, ainda tem se defrontado com dificuldades para ser efetivamente implantada, encontrando resistências por parte dos operadores do direito e da população que é atendida pelos programas, que não entendem o modelo enquanto expertise (caso dos profissionais do direito), ou como benefício para os envolvidos (caso dos adolescentes e familiares participantes), pois permanecem vinculados a uma perspectiva punitiva em relação à gestão de conflitos.

Raffaella Pallamolla (2017), em tese de doutorado defendida no PPG em ciências sociais da Pontifícia Universidade Católica do Rio Grande do Sul, aborda a construção da justiça restaurativa no Brasil com base nas narrativas dos protagonistas do processo, no discurso oficial sobre a justiça restaurativa e nas práticas restaurativas mais utilizadas. Ela apresenta a trajetória dos protagonistas e o contexto de suas primeiras experiências, abordando, além dos projetos-piloto, as primeiras publicaçôes sobre o tema, assim como a atual regulamentação da justiça restaurativa e o processo de elaboração da Resolução $\mathrm{CNJ} \mathrm{n}^{\circ}$ 225/2016. A autora considera que o desenvolvimento da justiça restaurativa no Brasil ocorre em duas ondas, nas quais o protagonismo do Poder Judiciário é a caraterística sobressalente, e constata a hegemonia do discurso da cultura da paz e da pacificaçẫo dos conflitos, associados à prática dos círculos restaurativos de Kay Pranis. Pallamolla argumenta, por fim, que a justiça restaurativa brasileira possui um déficit democrático, associado a uma tendência da cultura jurídica, observada não só em reformas legais anteriores, mas também em formas de participação na justiça criminal comum.

Em que pese a heterogeneidade dos trabalhos lidos por nós para esta revisão bibliográfica, em geral, os achados das pesquisas corroboram traços e tendências que conformam o sistema de justiça criminal no Brasil e já tinham sido descritos por pesquisas que se tornaram clássicas na antropologia e sociologia da administração institucional de conflitos produzida no país.

A maioria dos trabalhos analisados considera grande o peso das permanências autoritárias nas práticas judiciais e nas concepçôes e representaçóes sociais compartilhadas pelos atores institucionais. $\mathrm{O}$ peso da tradiçáo inquisitorial, a baixa adesão ao paradigma dos direitos humanos, a interveniência de moralidades que enfatizam hierarquias sociais e desigualdades, especialmente de classe e de gênero, foram características corroboradas por um conjunto robusto de resultados das pesquisas. A validação da violência como forma legítima de 
resolver conflitos também esteve presente em um conjunto importante de artigos e teses sobre o funcionamento da justiça criminal: crimes de homicídio são pouco punidos, a violência policial em geral não é punida e a violência contra a mulher encontra sérias barreiras para ser adequadamente administrada pelas vias judiciais.

As análises tendem a observar o impacto da desigualdade de classe no funcionamento da justiça penal brasileira, atribuindo a esta um papel relevante no controle social das classes populares. Praticamente não há estudos que apontam o uso da justiça criminal pelas classes populares para defender direitos e garantias - essas classes apareceram sempre na condição de quem tem seus direitos violados por práticas institucionais. Apenas a pesquisa de Kant de Lima e Mouzinho (2016) abordou as práticas inquisitoriais aplicadas a agentes das elites políticas e econômicas, indicando novas possibilidades de pesquisa a partir das grandes operaçôes policiais/judiciais no âmbito federal, mas apontando a permanência de padróes de funcionamento do campo vinculados ao decisionismo e a um novo ativismo judicial, que acabam por reforçar as características tradicionais da justiça penal e por distanciá-la de uma pretendida constitucionalizaçáo.

As desigualdades de gênero foram muito abordadas no período recente por pesquisas que enfocam a aplicação da Lei Maria da Penha e a administração judicial da violência contra a mulher. As desigualdades raciais no funcionamento da justiça penal, contudo, foram muito pouco discutidas nos estudos mais recentes publicados nas revistas de estrato A e nas teses, o que contrasta com uma virada antirracista já identificada nos estudos sobre polícia; quando aparece, raça é um atributo dos acusados de crimes, mas as relaçôes raciais náo foram mobilizadas como categoria analítica para compreender a desigualdade nas práticas judiciárias e nos processos de incriminação diferencial.
Se as permanências autoritárias nas práticas e resultados institucionais foram enfatizadas, um conjunto importante de estudos procurou avaliar o impacto de mudanças legislativas do período recente, posto que diversas áreas da política criminal passaram por reformas, como a política de drogas e de administração institucional da violência contra a mulher; o campo das alternativas penais também foi incentivado e ampliado, enquanto a criminalizaçáo dos delitos ligados à subtração do dinheiro público foi melhor descrita e para sua persecução foram abertas novas possibilidades processuais. Em meio às inovaçôes, as ciências sociais rapidamente responderam com avaliaçóes e monitoramento de resultados, talvez ainda insuficientes para uma visão mais ampla e conclusiva sobre as tendências em curso. As pesquisas tendem a enfatizar a emergência de novos conflitos institucionais, de saberes e de práticas no campo da administração institucional de conflitos, e buscam encontrar fissuras nas concepçôes e moralidades dos agentes judiciais. Mas quase todos os estudos demonstram a existência de enormes barreiras organizacionais e valorativas para o sucesso de inovaçóes na justiça criminal. O papel crescente do Ministério Público na definição das tendências judiciárias e o papel de instituiçóes alternativas ao sistema penal, seja a justiça restaurativa, seja a rede de atendimento e proteção às mulheres em situação de violência, são novos temas de pesquisas que emergiram nos últimos cinco anos.

A conclusão generalizada parece ser que, a despeito de existirem pressốes por inovação, por democratização e por ampliação de reconhecimento de direitos humanos, a ausência de reformas institucionais mais profundas não apenas obstaculiza seriamente o sucesso das inovaçôes, como também tornou o sistema de justiça criminal mais punitivo e encarcerador, reforçando o seu papel de reprodutor 
e legitimador das desigualdades que estão na origem dos conflitos. Considerando-se os estudos lidos e resenhados aqui, a experiência democrática dos últimos 30 anos não foi densa o suficiente para deslocar as instituiçóes judiciais de seu papel de defesa de privilégios e hierarquias. As instituiçốes da justiça criminal não se constituíram como espaço de defesa de direitos e reequacionamento das relaçóes de poder que produzem subalternidades de classe, gênero, geração, sexualidade, território, estilo de vida. As tendências apontadas nos estudos indicam a adesão hegemônica das instituiçóes judiciais a visốes conservadoras e autoritárias da ordem social, com crescente protagonismo dos juízes e tribunais em ações de conteúdo declaradamente político.

Em especial no âmbito das disputas em torno da resposta ao delito, a crescente percepção das novas geraçôes de operadores jurídicos sobre uma pretensa impunidade como principal explicação para o crescimento da criminalidade e da violência acabou por se vincular a uma demanda social punitiva, em grande medida capturada e amplificada ou direcionada pela mídia de massas, produzindo uma potente vertente político-criminal que vê nos direitos e garantias assegurados pela Constituição uma barreira para o combate ao crime e a criminalização de acusados.

Embora os trabalhos resenhados tenham identificado esse movimento e a sua vinculação ao histórico de atuação do sistema de justiça criminal no Brasil, ainda não se produziram trabalhos que procurem identificar também os traços de mudança e aprofundamento do punitivismo policial-judicial pós-1988, tendo em vista que até pouco tempo os estudos identificavam predominantemente uma inflexão mais positiva do campo jurídico em virtude do texto constitucional e da necessidade de afirmação de direitos e garantias. Compreender as mentalidades institucionais e corporativas do campo policial-judicial, levando em conta tanto as permanências e resistências à mudança quanto as novidades em termos de adesão a perspectivas que transcendem inclusive o âmbito nacional e se vinculam ao recrudescimento penal que emerge após o Onze de Setembro, colocando em questáo os princípios e regras do processo penal democrático, são questôes que se colocam de forma central para uma agenda de pesquisa da área no próximo período.

Se existem pressóes minoritárias por mudanças, emergência de moralidades insurgentes e práticas dissonantes, o prognóstico não é otimista: no atual quadro, as reivindicaçóes democratizantes náo encontram nas instituiçôes judiciais um guardião das promessas, e o "guarda da esquina" se percebe autorizado a resolver por conta própria uma conflitualidade social cada vez mais complexa e violenta.

\section{Referências}

ACHUTTI, D. Justiça restaurativa no Brasil: possibilidades a partir da experiência belga. Civitas, Porto Alegre, v. 13, n. 1, p. 154-181, 2013.

ALMEIDA, V. R. A atualização do princípio da legalidade penal através do exame de algumas práticas judiciárias. Dilemas, Rio de Janeiro, v. 5, n. 1, p. 67-99, 2012. 
AOKI, C. D. O conflito social no norte do Paraná: estudo descritivo e estatístico de banco de dados dos autos criminais do Fórum da Comarca de Londrina - 1934/1970. 2014. 200 f. Tese (Doutorado em Sociologia) - Setor de Ciências Humanas da Universidade Federal do Paraná, Curitiba, 2014.

AZEVEDO, R. G.; CIFALI, A. C. Política criminal e encarceramento no Brasil nos governos Lula e Dilma: elementos para um balanço de uma experiência de governo pós-neoliberal. Civitas, Porto Alegre, v. 15, n. 1, p. $105-127,2015$.

BARBOSA, A. C. F. Lei Maria da Penha: da convivência com as práticas do sistema de justiça no submédio do Vale do São Francisco. 2014. 240 f. Tese (Doutorado em Ciências Sociais) - Centro de Ciências Humanas, Letras e Artes da Universidade Federal do Rio Grande do Norte, Natal, 2014.

BERDET, M. B. Os significados da punição nas penas alternativas. 2015. 175 f. Tese (Doutorado em Sociologia) Universidade de Brasília, Brasília, DF, 2015.

BiTTENCOURT, M. B.; DADAlTO, M. C. Poder punitivo e teoria social. Dilemas, Rio de Janeiro, v. 9, n. 2, p. 271-292, 2016.

BROCCO, P. D. B. Explorando a estrutura da confiança: apontamentos em sociologia do direito a partir do funcionamento da Lei de Medidas Cautelares. Revista Direito GV, São Paulo, v. 12, n. 3, p. 667-690, 2016.

CAMPOS, C. H. Desafios na implementação da Lei Maria da Penha. Revista Direito GV, São Paulo, v. 11, n. 2, p. 391-406, 2015.

CAMPOS, M. S. Drogas e justiça criminal em São Paulo: uma análise da origem social dos criminalizados por drogas desde 2004 a 2009. Contemporânea, São Carlos, v. 5, n. 1, p. 167-189, 2015a.

Pela metade: as principais implicaçóes da nova lei de drogas no sistema de justiça criminal em São Paulo. 2015. 313 f. Tese (Doutorado em Sociologia) - Faculdade de Filosofia, Letras e Ciências Humanas, Universidade de São Paulo, São Paulo, 2015b.

CASTRO, F. L. Mulheres por direito: crimes na legislação, doutrina e jurisprudência em Vassouras 1860-1889. 2015. Tese (Doutorado em Sociologia e Direito) - Universidade Federal Fluminense, Niterói, 2015.

CONCEIÇÃO, A. C. L. Metendo a colher: os crimes passionais em Salvador (1940-1980). 2015. 254 f. Tese (Doutorado em Estudos Interdisciplinares sobre Mulheres, Gênero e Feminismo) - Faculdade de Filosofia e Ciências Humanas da Universidade Federal da Bahia, Salvador, 2015.

COSTA, A. T. M. A (in)efetividade da justiça criminal brasileira: uma análise do fluxo de justiça dos homicídios no Distrito Federal. Civitas, Porto Alegre, v. 15, n. 1, p. 7-10, 2015.

COSTA, D. S. D. A magistratura no Maranhão e as relaçôes de gênero: origens sociais, carreiras e representaçōes das juízas. 2015. 289 f. Tese (Doutorado em Ciências Sociais) - Universidade Federal do Maranhão, São Luís, 2015. 
DIAS, G. M. Migração e crime: desconstrução das políticas de segurança e tráfico de pessoas. 2014. 336 f. Tese (Doutorado em Antropologia Social) - Universidade Estadual de Campinas, Campinas, 2014.

DIÓGENES, J. L. S. O subsistema penal militar e suas contingências: uma sociologia do crime militar à luz de Niklas Luhmann. 2017. 189 f. Tese (Doutorado em Sociologia) - Universidade Federal do Ceará, Fortaleza, 2017.

EILBAUM, L.; MEDEIROS, F. Quando existe "violência policial”? Direitos, moralidades e ordem pública no Rio de Janeiro. Dilemas, Rio de Janeiro, v. 8, n. 3, p. 407-428, 2015.

FERREIRA, L. M. A.; MACHADO, M. R. A.; MACHADO, M. R. Massacre do Carandiru: vinte anos sem responsabilizaçấo. Novos Estudos Cebrap, n. 94, p. 5-29, 2012.

FREIXO, A.; SERRA, C. H. A.; MEDEIROS, D. O Estado de Direito no Brasil e suas incongruências: os direitos humanos em questão. Contemporânea, São Carlos, v. 2, n. 1, p. 65-82, 2012.

FULLIN, C. S. Quando o negócio é punir: uma análise etnográfica dos juizados especiais criminais e suas sanções. 2011. 256 f. Tese (Doutorado em Antropologia Social) - Universidade de São Paulo, São Paulo, 2011.

Gestão, tempo, trabalho e sofrimento: a economia das trocas punitivas a partir de uma etnografia de Juizados Especiais Criminais. Dilemas, Rio de Janeiro, v. 8, n. 1, p. 127-156, 2015.

GARCIA, C. S. Vidas esticadas, vidas descartadas: Estado repressivo, aparelho policial e sistema de justiça: uma análise de homicídios no pretenso contexto de valorização da vida. 2013. 304 f. Tese (Doutorado em Sociologia) Universidade Estadual de Campinas, Campinas, 2013.

GARCIA, I. J. A produção de Justiça: um estudo sobre o Juizado de Violência Doméstica e Familiar contra a Mulher. 2016. 229 f. Tese (Doutorado em Antropologia Social) - Universidade Federal de Santa Catarina, Florianópolis, 2016.

GERALDO, P. H. B.; BARÇANTE, L. F. S. A (des)confiança na polícia: uma comparação entre a relação do Ministério Público e a polícia no Brasil e na França. Civitas, Porto Alegre, v. 17, n. 1, p. 159-176, 2017.

KANT DE LIMA, R. Entre as leis e as normas: éticas corporativas e práticas profissionais na segurança pública e na Justiça Criminal. Dilemas, Rio de Janeiro, v. 6, n. 4, p. 549-580, 2013.

KANT DE LIMA, R.; MOUZINHO, G. M. P. Produção e reprodução da tradição inquisitorial no Brasil: entre delaçôes e confissões premiadas. Dilemas, Rio de Janeiro, v. 9, n. 3, p. 505-529, 2016.

LEONÍDIO, A. Ações penais e criminalização dos movimentos sociais de luta pela terra no Pontal do Paranapanema, SP, 1990-2014. Contemporânea, São Carlos, v. 6, n. 1, p. 159-177, 2016.

MACHADO B. A.; PORTO, M. S. G. Violência e justiça criminal na Área Metropolitana de Brasília: dinâmicas organizacionais e representaçôes sociais. Tempo Social, v. 28, n. 3, p. 217-242, 2016. 
MATSUDA, F. E. Sob fogo cruzado: a gestão de mulheres e a justiça criminal paulista. 2016. 200 f. Tese (Doutorado em Sociologia) - Universidade de São Paulo, São Paulo, 2016.

MELO, M. L. Sentir na sentença: direitos humanos, emoções e decisões judiciais. 2016. Tese (Doutorado em Ciências Sociais) - Universidade do Estado do Rio de Janeiro, Rio de Janeiro, 2016.

MENDONÇA FILHO, F. P. Velhos usuários e jovens traficantes? Um estudo de caso sobre a atualização da nova Lei de Drogas na cidade do Rio de Janeiro. Dilemas, Rio de Janeiro, v. 6, n. 1, p. 11-37, 2013.

MENEZES, A. B. Tecnologias de poder e corpo humano: imagens de cidadania criminal. 2015. 193 f. Tese (Doutorado em Ciências Sociais) - Pontifícia Universidade Católica de São Paulo, São Paulo, 2015.

MORENO, R. F. P. G. Reflexão sobre a efetividade da proteção ambiental no Brasil: uma análise sociológica e jurídica sobre a lei de crimes ambientais. 2013. 233 f. Tese (Doutorado em Ciências Sociais) - Universidade Estadual de Campinas, Campinas, 2013.

ODON, T. I. A linguagem penal do contrato social brasileiro: o inimigo, a guerra e a construção da ordem contra a sociedade no Brasil (1822-1890). 2013. Tese (Doutorado em Sociologia) - Universidade de Brasília, Brasília, DF, 2013.

OLIVEIRA, C. G. "Na maior brevidade possível”: tensōes na administração da justiça em uma vara criminal do DF. 2012. 206 f. Tese (Doutorado em Sociologia) - Universidade de Brasília, Brasília, DF, 2012.

PALLAMOLLA, R. P. A construção da justiça restaurativa no Brasil e o protagonismo do Poder Judiciário: permanências e inovaçôes no campo da administração de conflitos. 2017. 286 f. Tese (Doutorado em Ciências Sociais) - Pontifícia Universidade Católica do Rio Grande do Sul, Porto Alegre, 2017.

PASINATO, W. Acesso à justiça e violência doméstica e familiar contra as mulheres: as percepçóes dos operadores jurídicos e os limites para a aplicação da Lei Maria da Penha. Revista Direito GV, São Paulo, v. 11, n. 2, p. 407-428, 2015.

PASSOS, T. E. L. O espetáculo da Justiça: uma etnografia do Tribunal do Júri. 2013. 409 f. Tese (Doutorado em Antropologia) - Universidade de Brasília, Brasília, DF, 2013.

PASTANA, D. R. Estado punitivo brasileiro: a indeterminação entre democracia e autoritarismo. Civitas, Porto Alegre, v. 13, n. 1, p. 27-47, 2013.

PENNA, P. D. M.; BELO, F. R. R. Crítica à alteração da Lei Maria da Penha: tutela e responsabilidade. Psicologia, Brasília, DF, v. 32, n. 3, p. 1-8, 2016.

POSSAS, M. Produção de leis criminais e racionalidade penal moderna: uma análise da distinção "conservador" x "progressista” no caso da criação da lei contra a tortura no Brasil. Dilemas, Rio de Janeiro, v. 8, n. 3, p. 473-499, 2015.

PRADO, A. M.; SCHINDLER, D. A medida de segurança na contramão da Lei de Reforma Psiquiátrica: sobre a dificuldade de garantia do direito à liberdade a pacientes judiciários. Revista Direito GV, Sáo Paulo, v. 13, n. 2, p. 628-652, 2017. 
PRUDENTE, M. D. F. Pensar e fazer justiça: a administração alternativa de conflitos no Brasil. 2012. 289 f. Tese (Doutorado em Sociologia) - Universidade de Brasília, Brasília, DF, 2012.

RAMOS, M. Reflexôes sobre o processo histórico-discursivo do uso da legítima defesa da honra no Brasil e a construção das mulheres. Revista Estudos Feministas, Florianópolis, v. 20, n. 1, p. 53-73, 2012.

REGINATO, A. D. A. Obrigaçâo de punir: racionalidade penal moderna e as estratégias de controle da violência doméstica contra a mulher. 2014. 253 f. Tese (Doutorado em Sociologia) - Universidade Federal de Sergipe, São Cristóvão, SE, 2014.

REIS, I. M. L. Diálogos e conflitos entre campos de conhecimento: o Ministério Público após a Lei Maria da Penha. 2016. 370 f. Tese (Doutorado em Antropologia) - Universidade de Brasília, Brasília, DF, 2016.

RIBEIRO, L. M. L.; MACHADO, I. S.; SILVA, K. A. A reforma processual penal de 2008 e a efetivação dos direitos humanos do acusado. Revista Direito GV, Sáo Paulo, v. 8, n. 2, p. 677-702, 2012a.

Tempo na ou da justiça criminal brasileira: uma discussão metodológica. Opiniäo Pública, Campinas, v. 18, n. 2, p. 355-382, 2012b.

RIBEIRO, L. M. L.; ROCHA, R. L. S.; COUTO, V. A. Nas malhas da justiça: uma análise dos dados oficiais de indiciados por drogas em Belo Horizonte (2008-2015). Opiniāo Pública, Campinas, v. 23, n. 2, p. 397-428, 2017.

RICHTER, V. S. Identificação genética e crime: a introdução dos bancos de DNA no Brasil. 2016. Tese (Doutorado em Antropologia Social) - Universidade Federal do Rio Grande do Sul, Porto Alegre, 2016.

RIFIOTIS, T. Violência, justiça e direitos humanos: reflexôes sobre a judicialização das relaçóes sociais no campo da “violência de gênero". Cadernos Pagu, Campinas, n. 45, p. 261-295, 2015.

ROCHA, A. R. D. A moral e o direito no julgamento dos crimes contra o patrimônio: uma investigaçáo sobre os processos criminais decididos pelo Poder Judiciário da comarca de Montes Claros-MG após a Constituição Federal de 1988. 2016. Tese (Doutorado em Ciências Sociais) - Universidade do Estado do Rio de Janeiro, Rio de Janeiro, 2016.

RODRIGUES, E. E. M. A cultura punitiva na modernidade tardia: um estudo das racionalidades legislativas do sistema penal brasileiro. 2016. 256 f. Tese (Doutorado em Sociologia) - Universidade Federal de Pernambuco, Recife, 2016.

RODRIGUES, H. A pedofilia e suas narrativas: uma genealogia do processo de criminalização da pedofilia no Brasil. 2014. 322 f. Tese (Doutorado em Sociologia) - Universidade de São Paulo, Sáo Paulo, 2014.

RODRIGUEZ, J. R. "Utopias" institucionais antidiscriminação: as ambiguidades do direito e da política no debate feminista brasileiro. Cadernos Pagu, Campinas, n. 45, p. 297-329, 2015.

ROLIM, R. C.; RODRIGUES, F. C. M. O assassinato de um homossexual diante de um tribunal da Capital da República em meados do século XX. Revista Estudos Feministas, Florianópolis, v. 21, n. 1, p. 325-342, 2013. 
SANTOS, F. M. "Linhas de investigação": uma etnografia das técnicas e moralidades sobre "homicídios" na Polícia

Civil da Regiáo Metropolitana do Rio de Janeiro. 2016. 293 f. Tese (Doutorado em Antropologia) - Universidade Federal Fluminense, Niterói, 2016.

SILVA, L. S. Bater em mulher dá cadeia! Análise sociocultural da punição na Lei Maria da Penha. 2014. Tese (Doutorado em Ciências Sociais) - Pontifícia Universidade Católica de São Paulo, São Paulo, 2014.

SILVA, S. S. Todos são culpados? Uma etnografia na Auditoria de Justiça Militar do Estado do Rio de Janeiro. 2013. 208 f. Tese (Doutorado em Antropologia) - Universidade Federal Fluminense, Niterói, 2013.

SILVESTRE, G. "Enxugando iceberg”: como as instituiçôes estatais exercem o controle do crime em São Paulo. 2016. 314 f. Tese (Doutorado em Sociologia) - Universidade Federal de São Carlos, São Carlos, 2016.

SIMIÃO, D. S.; OLIVEIRA, L. R. C. Judicializaçẫo e estratégias de controle da violência doméstica: a suspensão condicional do processo no Distrito Federal entre 2010 e 2011. Sociedade e Estado, Brasília, DF, v. 31, n. 3, p. 845-874, 2016.

SOUZA, C. C. Judiciário e autoritarismo: ação política da Suprema Corte de Justiça do Brasil e da Argentina no julgamento de crimes políticos. 2015. 232 f. Tese (Doutorado em Estudos Comparados sobre as Américas) Universidade de Brasília, Brasília, DF, 2015.

SOUZA, G. A. D.; AZEVEDO, R. G. Alternativas penais no Brasil após 1984 e seus efeitos: uma análise a partir de discursos sobre crime e punição. Contemporânea, São Carlos, SP, v. 5, n. 1, p. 69-92, 2015.

TONCHE, J. A construção de um modelo "alternativo" de gestão de conflitos: usos e representaçōes de justiça restaurativa no estado de São Paulo. 2015. 223 f. Tese (Doutorado em Sociologia) - Universidade de São Paulo, São Paulo, 2015.

VASCONCELLOS, F. B. A família, a violência e a justiça: conflitos violentos familiares, Lei Maria da Penha e concepçôes jurídicas no Tribunal de Justiça do Rio Grande do Sul. Civitas, Porto Alegre, v. 13, n. 1, p. 136-153, 2013.

Punir, proteger, prevenir? A Lei Maria da Penha e as limitaçôes da administração dos conflitos conjugais violentos através da utilização do Direito Penal. 2015. 224 f. Tese (Doutorado em Ciências Sociais) - Pontifícia Universidade Católica do Rio Grande do Sul, Porto Alegre, 2015.

VENSON, A. M. Tráfico internacional de pessoas para exploração sexual? Uma análise de processos-crime (1995-2012). Revista Estudos Feministas, Florianópolis, v. 25, n. 2, p. 571-591, 2017.

Tráfico internacional de pessoas para exploração sexual? Uma análise de processos-crime (1995-2012). 2015. 421 f. Tese (Doutorado Interdisciplinar em Ciências Humanas) - Universidade Federal de Santa Catarina, Florianópolis, 2015.

VIEIRA, F. M. C. Sob o leito do Procusto: sistema judicial e a criminalização da luta pela terra no Rio Grande do Sul. 2012. 290 f. Tese (Doutorado em Ciências Sociais, em Desenvolvimento, Agricultura e Sociedade) - Universidade Federal Rural do Rio de Janeiro, Rio de Janeiro, 2012. 


\section{Resumo}

O sistema de justiça criminal na perspectiva da antropologia e da sociologia

Este artigo é uma revisão bibliográfica de estudos sobre justiça criminal cujo escopo são artigos publicados em revistas do extrato A das áreas de sociologia e antropologia e das teses defendidas nos programas de pós-graduação das mesmas áreas, no período de cinco anos. Além das orientaçôes teóricas e metodológicas, notou-se a importância dos estudos de fluxo, de pesquisas sobre representaçôes e visôes criminológicas dos operadores judiciais, da administração dos conflitos de gênero, da incriminaçáo dos delitos por drogas e da discussão das alternativas penais, em especial a justiça restaurativa. Destacam-se as conclusóes que identificam a permanência de tendências autoritárias e punitivistas da justiça criminal.

Palavras-chave: Justiça Criminal; Justiça Penal; Punitivismo; Operadores Judiciais; Administraçẫo Institucional de Conflitos.

\section{Abstract}

The criminal justice system under the anthropological and sociological perspective

The article is a review of criminal justice studies based on articles published in journals of the extract A of Sociology and Anthropology and of theses defended in post-graduate programs from these areas, in the period of five years. In addition to the theoretical and methodological guidelines, we have observed the importance of flow studies, of research on representations and criminological visions of judicial operators, of gender conflict management, the incrimination of drug offences, and of the discussion of criminal alternatives, especially restorative justice. The conclusions that identify the permanence of authoritarian and punitive trends in criminal justice are highlighted.

Keywords: Criminal Justice; Penal Justice; Punitive Trends; Judicial Operators; Institutional Conflict Management

\section{Résumé}

\section{Le système de justice pénale du point de vue de l'anthropologie et de la sociologie}

Cet article est une revue bibliographique d'études sur la justice pénale basée sur des articles publiés dans des revues de l'extrait A des domaines de sociologie et d'anthropologie et des thèses soutenues dans les programmes postuniversitaires des mêmes domaines, dans la période de cinq ans. En plus des orientations théoriques et méthodologiques, on a observé l'importance des études de flux, des recherches sur les représentations criminelles et les visions criminologiques des opérateurs judiciaires, de l'administration des conflits de genre, de la criminalisation des infractions en matière de drogue et de la discussion des alternatives criminelles, surtout la justice réparatrice. On souligne les conclusions qui identifient la persistance des tendances autoritaires et punitives de la justice pénale.

Mots-clés: Justice Criminelle; Justice Pénale; Punitivisme; Opérateurs Judiciaires; Gestion Institutionnelle des Conflits. 